\title{
Diversity of Aquatic Insects in Karamana River, Southern Western Ghats, India
}

\author{
Bismi L. S. ${ }^{1}$, P. Madhusoodanan Pillai ${ }^{2}$ \\ ${ }^{1}$ Department of Zoology, Mahatma Gandhi College, Thiruvananthapuram, India \\ ${ }^{2}$ Central Agricultural University, Imphal, Manipur
}

\begin{abstract}
The River Karamana, a west flowing perennial drainage originates from the hills of Agasthyarkoodam, part of Southen Western Ghats.The present studywill contribute towards the knowledge of the assessment of population and species diversity of aquatic insects of the River.Monthly sampling of aquatic insects was conducted at seven stations of the river during May 2014 to Oct.2014. A total of 47 genera belong to 7 orders and28 families were identified. Among them, the order Hemiptera (46\%) was the most dominant, followed by the order Coleoptera (22\%).Statistical analysis was done by appropriate statistical tools. The study shows many parts of the river startedto deteriorate hence the complete absence or less abundance of sensitive/ pollution intolerant species are less in the study. Thereforeimmediate attention and proper maintenance of the river is to be suggested.
\end{abstract}

Keywords: Aquatic insect, Diversity, River Karamana, Southern western Ghats, Kerala

\section{Introduction}

Insects are the most species-rich and have successfully invaded virtually all aquatic habitats. They often exhibit high diversity (Anne, E.H. et. al., 2010). Aquatic insects are significant in many ways such as processing organic matter and transporting energy along stream channels etc.(Hynes, 1970,Malmqvist,2002).According to Lewis and Gripenberg (2008), aquatic insects are present in some quantity in almost every type of habitat and many are habitat specialists so that they often make good indicators. Because of their differential responses to stimuli in their aquatic habitat and determining the quality of that environment aquatic insects are used for monitoring the health of aquatic environments (Merritt R.W; K.W. Cummins and M.B. Berg 2008). Some of these insects may be beneficial to human being, and some of them are quite harmful to us (Ahmed, 1983). At the larval stage, they constitute the principal nutritive fauna of fish (Minshal 2003;Tachetet.al.,2003).

Subramanian and Sivaramakrishnan (2007) estimated about 5,000 species of aquatic insects in inland wetlands of India. Studies of Aquatic Hemiptera of Pocharam Lake in Andhra Pradesh were done by Deepa and Rao in 2007. Diversity and Distribution of Aquatic Insects in Aghanashini River of Central Western Ghats of India were studied by Balachandranet. al. in 2012. Some other studies on aquatic insects reported in India by Tonapy (1954), Ahmed (1983), Mishra and Saxena (1984), Thirumalai (1999), Bhattacharya (1998), Bhandarkar and Bhandarkar (2013), Barman and Gupta $(2015 ; 2016)$.

Very few studies on aquatic insects in Kerala have been reported so far. Due to limited knowledge of the taxonomy and distribution of aquatic insects in the country, most of the studies have been confined to supra-specific taxonomic levels.

Karamana is one of the major rivers flowing through Thiruvananthapuram district, Kerala. This is a small falls mountainous river draining the Western Ghats. The present study will contribute towards the knowledge of the assessment of population and species diversity of aquatic insects of Karamana River.

\section{Materials and Methods}

\section{StudyArea}

The River Karamana originates from Agastyarkoodam hills, the southern tip of the Western Ghats and flows through the Thiruvananthapuram, the capital city of the State Kerala. The river flows $68 \mathrm{~km}$ westward and meanders their way to the Arabian Sea at Thiruvallam. Seven stations were selected for the present study during May 2014 to October 2014 period. They were Aruvikkara (Station 1- $8^{0} 44^{\prime}$, $76^{0} 95^{\prime}$ ), Irumba (Station 2-8 $\left.46^{\prime} 76^{0} 97^{\prime}\right)$, Vellaikadavu (Station 3-8 47', 76 98'), Thrikkannapuram (Station 4 $\left.8^{0} 47^{\prime}, 77^{0} 00^{\prime}\right)$, Parayilkadavu (Station $5-8^{0} 53^{\prime}, 77^{0} 01^{\prime}$ ), Maruthoorkadavu (Station $6-8^{0} \quad 56^{\prime}, \quad 77^{0} \quad 00^{\prime}$ ) and Thiruvallam (Station $7-8^{0} 57^{\prime}, 77^{0} 02^{\prime}$ '). The samplings were done between $6.30 \mathrm{am}$ and $11.30 \mathrm{am}$ on every month.The study is aimed at compiling the first inventory of the aquatic insect diversity of Karamana river of Kerala.

\section{Methodology}

Aquatic insects were collected monthly from different stations of the river by the nylon pond net method (Subramanian KA, Sivaramakrishnan KG, 2007). The insects were sorted, counted and identified by using standard keys (Thirumalai, 1999,2002; Jessup et.al.,2003;Bahl and Basu, 2004; Neiser,2004; Epler,2006; Gupta and Chaturvedi,2008; Webb and Mccafferty,2008). For identification, only two or three specimens were used and the rests were returned to the sites after counting.

\section{Data Analysis}

By using statistical tools, data were analysed. Prior to this Normality tests were done by PAST 3.12. The ShannonWeiner index and Simpson dominance index were 


\section{International Journal of Science and Research (IJSR) \\ ISSN (Online): 2319-7064}

Index Copernicus Value (2013): 6.14 | Impact Factor (2015): 6.391

determined for each station to analyse the species diversity and component of dominance respectively. Buzas and Gibson's evenness $(\mathrm{eH} / \mathrm{S})$ index was used to calculate relative abundance of each insect order for each station.

\section{Results and Discussion}

Insect Fauna: The present study recorded 833 individuals which were belonged to 7 orders of aquatic insects (Odonata, Hemiptera, Coleoptera, Ephemeroptera, Diptera, Trichoptera, Megaloptera), 28families (Coenagrionidae, Libellulidae, Gomphidae of order Odonata;Nepidae, Pleidae, Belostomatidae, Naucoridae, Gerridae, Notonectidae,Veliidae, Mesoveliidae, Microveliidae, Helotrephidaeof the orderHemiptera;Elmidae, Hydrophilidae, Dytiscidae, Limnichidae of order Coleoptera;Leptoceridae of order Trichoptera; Chironomidae and Sciomyzidaeof orderDiptera; Caenidae,Baetidade, Ephemerellidae, Heptageniidae, Leptophlebiidae of order Ephemeroptera; Corylladidae of order Megaloptera), 47 genera and 49 species. They were represented by 12 species of order Odonata (14), 19 species of order Hemiptera $(36 \%), 7$ species of order Coleoptera (14\%), 2 species of order Trichoptera (7\%), 2 species of order Diptera $(7 \%), 5$ species of order Ephemeroptera (18\%), and 1 species of order Megaloptera (4\%)(Fig.1).Here, order Hemiptera was the most dominant in the River Karamana. Takhelmayum and Gupta (2011) reported similar abundance of hemiptera in Loktak Lake, Manipur. However Abhijnaet.al.,(2013) in Vellayani Lake, Kerala and Sharma andRai(1991) in Bhagalpur, Bihar found insects of Coleoptera to be the most common. In the present study, Coleopterawas the second dominant order.

Family-level distribution : FamilyLibellulidae (Order: Odonata) were more species rich (4 species) and that of Notonectidae (Order Hemiptera) was the most individualized (231 insects) family accounting for $27.73 \%$ of the total individuals recorded in the study. The families Coenagrionidae (54 members), Gomphidae (31 members), Nepidae (50 members),Gerridae (12 members) and Hydrophilidae (58 members) were recorded by 3 species each. Families Pleidae (14 members), Belostomatidae (5 members),Naucoridae (28 members), Notonectidae (231 members) ,Helotrephidae (7 individuals) and Dytiscidae (23 members) were recorded by 2 species each. The rest of the familesVeliidae (1 members), Mesoveliidae (6 members), Microveliidae (1 member), Elmidae (24members), Limnichidae (73 members), Leptoceridae (7 members), Chironomidae (43members), Sciomyzidae (1 member), Caenidae (14 members), Baetidae (22 members), Ephemerellidae (3 members), Heptageniidae(6 members), Leptophlebiidae (6 members) andCorylladidae (5members) were recorded by 1 species each.Family level distribution was shown in Table 1.

Table 1: Family-wise distribution of aquatic insects showing number of species in Karamana River during the study period

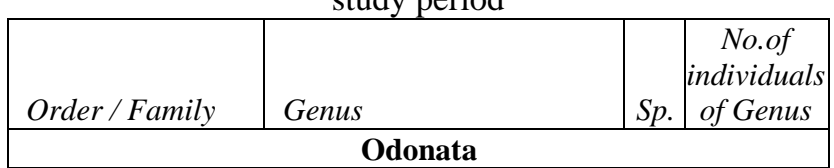

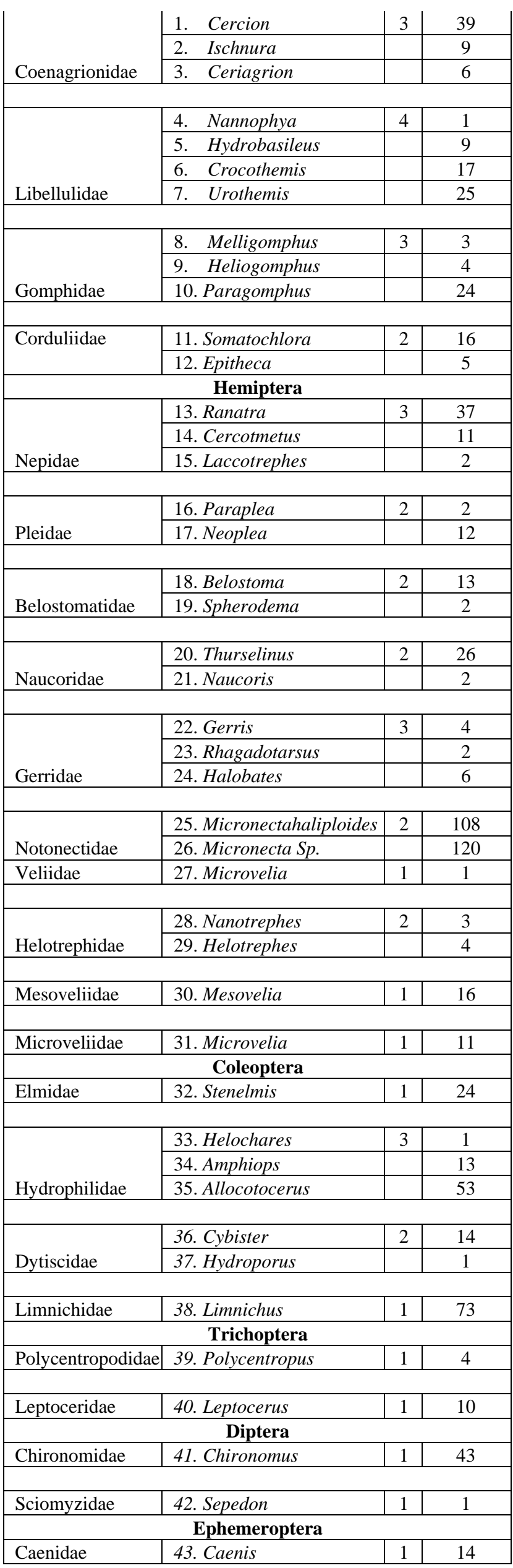

\section{Volume 5 Issue 6, June 2016 www.ijsr.net}

Licensed Under Creative Commons Attribution CC BY 
International Journal of Science and Research (IJSR)

ISSN (Online): 2319-7064

Index Copernicus Value (2013): 6.14 | Impact Factor (2015): 6.391

\begin{tabular}{|c|c|c|c|}
\hline Baetidae & 44. Baetis & 1 & 22 \\
\hline Ephemerellidae & 45. Ephemerella & 1 & 3 \\
\hline Heptageniidae & 46. Epeorus & 1 & 6 \\
\hline Leptophlebiidae & 47. Habrophlebiodes & 1 & 6 \\
\hline \multicolumn{4}{|c|}{ Megaloptera } \\
\hline Corylladidae & 48. Corydalus & 1 & 5 \\
\hline & Total & 48 & 833 \\
\hline
\end{tabular}

The Station-wise abundance of aquatic insects inRiver Karamana showed that maximum abundance (364) was recorded in station 1 and minimum (36) in station 7 . This reveals that the more human intervention adversely affect the abundance and diversity of aquatic insect. Major Disturbance in Station 7 was at its highest with people fetching water. The work done by Kyerematen and Gordon(2012) affirms this for their studies in three river systems in Ghana.Ephemeroptera were present in all stations throughout the study period and recorded high abundance in Station 1. This revealed that Station 1 is a pollution-free site hence the insect is a pollution-intolerant (J.V.Ward, 1992).

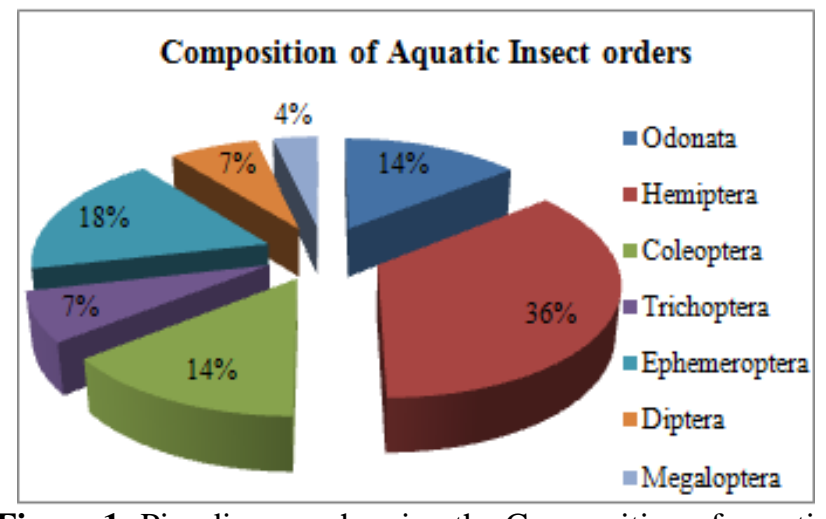

Figure 1: Pie- diagram showing the Composition of aquatic insects Orders during a period of six months

\section{Diversity and Species Richness}

Shannon index is a sensitive indicator of pollution. The result of Diversity indices analysis showed that, all the stations show a good diversity $(>1)$ of insectsexcept station 4. This is clearly perceived that the station 4 is under degradation of habitat structure. Station 6 recorded the maximum diversity (Shannon index $\mathrm{H}$ ) of 1.5 and the Simpson index was 0.75 and minimum dominance (D) of 0.24 for the entire sampling period. Minimum diversity of 0.86 and highest dominance of 0.56 were seen in station 4 . The Evenness of distribution of aquatic insects in the stations of river ranged from 0.47 to 0.83 in the stations 4 and 7 respectively.

Table 2:.Diversity indices of aquatic insects in Karamana River during the study period

\begin{tabular}{|c|c|c|c|c|c|c|c|}
\hline & Station 1 & Station 2 & Station 3 & Station 4 & Station 5 & Station 6 & Station 7 \\
\hline Taxa_S & 6 & 4 & 6 & 5 & 6 & 6 & 5 \\
\hline Individuals & 364 & 74 & 118 & 116 & 57 & 68 & 36 \\
\hline Dominance_D & 0.321 & 0.3338 & 0.4108 & 0.5667 & 0.329 & 0.2439 & 0.2593 \\
\hline Simpson_1-D & 0.679 & 0.6662 & 0.5892 & 0.4333 & 0.671 & 0.7561 & 0.7407 \\
\hline Shannon_H & 1.338 & 1.2 & 1.094 & 0.8659 & 1.391 & 1.538 & 1.431 \\
\hline Evenness_e^H/S & 0.6353 & 0.8298 & 0.4978 & 0.4754 & 0.6697 & 0.776 & 0.8366 \\
\hline
\end{tabular}

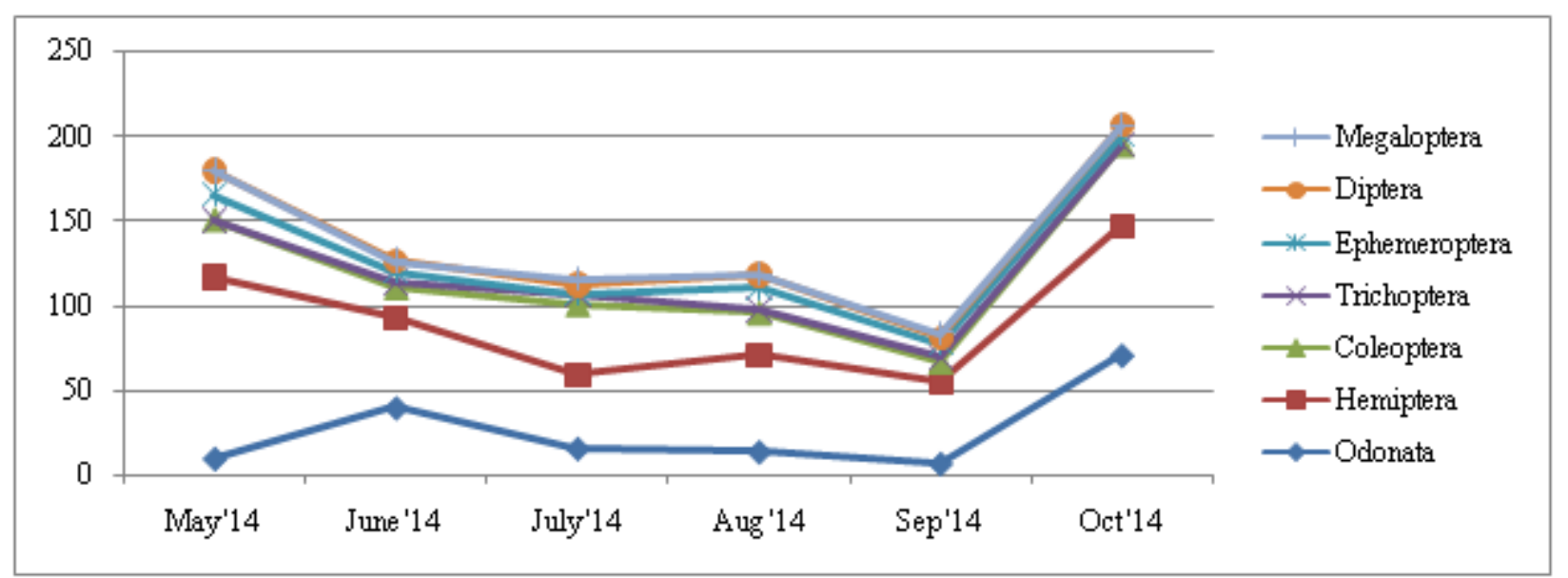

Figure 2: Population Dynamic of Aquatic Insect (Order) in Karamana River from May 2014 to November 2014

Figure 2 shows that the population of insect orders fluctuated throughout study period. A decreasing trend of insect abundance was seen from May to November 2014. The highestpopulation was recorded in November 2014. Subsequently, the least population was recorded in September2014 except the orderOdonata.

\section{Conclusion and Recommendations}

The result of the present work revealed that there are 8330 individuals of aquatic insects sampled in seven stations from May 2014 to Dec 2014. They belonged to 7 orders and 26 families, 44 genera and 45 species. Among them, the order Hemiptera $(46 \%)$ was the most dominant, followed by the order Coleoptera $(22 \%)$. Dominance of hemipteran and

\section{Volume 5 Issue 6, June 2016} www.ijsr.net 


\section{International Journal of Science and Research (IJSR) \\ ISSN (Online): 2319-7064}

Index Copernicus Value (2013): 6.14 | Impact Factor (2015): 6.391

coleopteran insects suggested that the River is relatively less polluted.The abundance of the aquatic insect recorded as the highest number during November 2014 in Karamana River. Station I is rich in vegetation and unpolluted. So the Dytiscidae population was higher than any other stations during the study period.The Station-wise abundance of aquatic insects in River Karamana showed that maximum abundance (364) was recorded in station 1 and minimum (36) in station 7 . This reveals that the more human intervention adversely affect the abundance and diversity of aquatic insect.

Many aquatic insects are very sensitive to changes in levels of pollutants in the water and are therefore used as indicators of the ecological well-being of these river systems (Kyerematen and Gordon, 2012). Therefore they should be preserved. Hence they play a significant role in maintaining the health of the ecosystems by being part of the food chain, cleaning up the system as scavengers and contributing immensely to decomposition of dead organic matter, their decrease will therefore result in the disruption of critical ecosystem services (Kyerematen and Gordon, 2012). The study shows that Station 1 is the species rich site and Station 4 is less diverse site. Many of the part of the river started to deteriorate hence the complete absence or less abundance of sensitive/ intolerant species are less in the study. Therefore immediate attention and proper maintenance of the river is to be suggested.

\section{Acknowledgements}

The authors are thankful to the PG Department of Zoology and Research Centre, Mahatma Gandhi Collge, Thiruvananthapuram, Kerala,for providing laboratory facility. Authors are grateful to the KSCSTE, Pattom, Thiruvananthapuram for the financial support.

\section{References}

[1] Abhijna, U.G., Ratheesh, R. and Bijukumar, A., 2013. Distribution and diversity of aquatic insects of Vellayanilake in Kerala. Journal of Environmental Biology, Vol.34, 605-611.

[2] Ahmed, A K Ziauddin., 1983: Studies on the Ecology of aquatic Insects With special reference to fish Pond, Ph.D. thesis North eastern Hill University, Meghalaya, India.

[3] Anne E. H., Gary A. L., Dominic T. C. and Robert M. N., 2010. Aquatic Insect Ecology. In: Ecology and Classification of North American Freshwater Invertebrates, $3^{\text {rd }}$ Ed. Edited by J. H. Thorp and A. P. Covich. (Academic Press), California, USA: 659-694.

[4] Bahl A, Basu RC. , 2004. State Fauna Series 10: Fauna of Manipur. ZSI. Kolkata, 625

[5] Balachandran, C., S. Dinakaran, M.D.S. Chandran and T.V. Ramachandra ; 2012. Diversity and Distribution of Aquatic Insects in Aghanashini River of Central Western Ghats, India. National Conference on Conservation and Management of Wetland Ecosystems. School of Environmental Sciences, Mahatma Gandhi University, Kottayam, Kerala: 1-10.
[6] Thirumalai, G. 1999. Aquatic and semi-aquatic Heteroptera of India, Indian Association of Aquatic Biologists, Hyderabad; 7:74

[7] Bijita Barman and Susmita Gupta, 2016. Tropical Ecology 57(2): 243-253.

[8] Barman, B. and S. Gupta. 2015. Aquatic insects as bioindicator of water quality- A study on Bakuamari stream, Chakrashila Wildlife Sanctuary, Assam, North East India Journal of Entomology and Zoology Studies. Vol. 3(3): 178-186

[9] Bhattacharya, D K. 1998. Insect fauna associated with large water hyacinth in freshwater wetlands of West Bengal. Biodiversity and Environment, Proceedings of the National Seminar on Environmental Biology, Daya Publishing House, Delhi, 145-147pp.

[10] Bhandarkar S.V. and Bhandarkar W.R., 2013: A study on species diversity of benthic macro invertebrates in freshwater lotic ecosystems in Gadchiroli district Maharashtra. Int. J. of Life Sciences, 2013 Vol.1 (1): 22-31 ISSN: 2320-7817

[11] Deepa,J. and C.A.N. Rao 2007: Aquatic Hemiptera of Pocharam Lake, Andhra Pradesh. Zoos' Print J., 22, 2937-2939.

[12] Epler J.H.,2006. Identification Manual for the Aquatic and Semiaquatic Heteroptera of Florida (Belostomatidae, Corixidae, Gelastocoridae, Gerridae, Hebridae, Hydrometridae, Mesoveliidae, Naucoridae, Nepidae, Notonectidae, Ochteridae, Pleidae, Saldidae, Veliidae).Florida Department of Environmental Protection, Tallahassee, FL, 186

[13] Gupta YC, Chaturvedi D.K., 2008. On A New Species of Water Skater, PtilomeraAmyot and Serville, 1843 from India (Hemiptera: Heteroptera, Gerridae). Asian J ExpSci; 22:165-170

[14] PAST 3.2. Hammer, Ø. \& Harper, D.A.T. 2006. Paleontological Data Analysis. Blackwell.

[15] Hynes, H.B.N., 1970. The Ecology of Running Waters. Liverpool University Press, Liverpool.

[16] Ward, J.V., 1992:In Aquatic Insect Ecology, John Wiley \& Son, Inc.

[17] Jessup BK, Markowitz A, Stribling JB, Friedman E, Labelle K, Dziepak N.,2003. Family- level key to the stream invertebrates of maryland and surrounding areas. Third Edition. (Maryland Department of Natural Resources. Section 10, 98

[18] Kyerematen, R. and C. Gordon, 2012. Aquatic Insect Fauna of Three River Systems in the AkyemAbuakwa Traditional area of The Eastern Region of Ghana. West African Journal of Applied Ecology, Vol. 20 (3), 73-82.

[19] Lewis, O.T. and Gripenberg, S. 2008. Insect seed predators and environmental change. Journal of Applied Ecology, 45 (6): 1593- 1599

[20] Malmqvist, B., 2002. Aquatic invertebrates in riverine landscapes. Freshwater Biology 47, 679-694.

[21] Merritt, R. W., K. W. Cummins, and M. B. Berg (eds). 2008. An Introduction to the Aquatic Insects of North America (4th ed.). Kendall/Hunt Publ. Co., Dubuque, IA $1158 \mathrm{pp}$.

[22] Minshall, G. W., 2003. Responses of stream benthic macroinvertebrates to fire. Forest Ecology and Management; 178:155-161. 


\section{International Journal of Science and Research (IJSR) \\ ISSN (Online): 2319-7064}

Index Copernicus Value (2013): 6.14 | Impact Factor (2015): 6.391

[23] Mishra, N. A. B. Saxena, 1984. The effect of sewage on special reference to aquatic Insect in the river Kshipra (India) Int. J. Env. Studies, 23, 191- 208.

[24] Nieser, N., 2004. Guide to aquatic heteroptera of Singapore and Peninsular Malaysia III. Pleidae and Notonectidae. The Raffles Bulletin of Zoology; 52:7996.

[25] Sharma, U.P. and D.N. Rai, 1991. Seasonal variations and species diversity of coleopteran insects in a fish pond of Bhagalpur. J. Freshwater Biol., 3: 241-246.

[26] Subramanian, K.A. and K. G. Sivaramakrishnan 2007: Aquatic Insects of India- A Field Guide. Ashoka Trust for Ecology and Environment (ATREE). Bangalore, India, pp.62

[27] Tachet H, Richoux P, Bournaud M, Usseglio-Polatera P., 2003. Invertébrésd'eaudouce: systématique, biologie, écologie. CNRS Edn, Paris, 587.

[28] Takhelmayum, K. and S. Gupta, 2011. Distribution of aquatic insects in phumdis (floating island) of Loktak Lake, Manipur, North-eastern India. JoTT., 3: 18561861.

[29] Thirumalai, G. 2002. A check list of Gerromorpha (Hemiptera) from India. Records of Zoological Survey of India; 100:55-97.

[30] Tonapi, G T., 1954: Studies on the aquatic insect fauna of poona (Aquatic Heteroptera), Proceedings of National Institute of Science.

[31] Webb JM, Mccafferty WP. Heptageniidae of the World, 2008. Part II: Key to the Genera. Can J Arthropod Identif 2008; 7:1-55. 